\title{
Semiotic and Cognitive Aspects of Professional Discourse Study
}

\section{Elena Aznacheeva}

Doctor of Philological Sciences, Professor, Chelyabinsk State University

aznacheeva.elena@yandex.ru

\section{Yuliia Mamonova}

Candidate of Philological Sciences, Head of the English Department Chelyabinsk State University kalina5771@mail.ru

\section{Doi:10.5901/mjss.2015.v6n6s5p30}

\begin{abstract}
The authors focus on some cognitive and semiotic aspects of professional discourse study. Different approaches towards the definition of professional discourse are highlighted. From the cognitive perspective professional world view is analyzed. It is said that terminology constitutes the core of professional world view; some means of categorization and conceptualization in various types of professional discourse are presented. The role of conceptual metaphor and metonymy as means of world categorization and conceptualization in professional communication is revealed. Describing the structure of professional consciousness the authors suggest an ethnocultural component. The background of semiotic research of professional discourse is analyzed on the level of metalanguage and professional speech communication. The sign character of professional discourse on the metalanguage level is represented by the language for specific purposes. The systematic character of professional speech communication is witnessed in the organization of speech genres, functioning of intertextual incorporations and precedent texts, communicative situations typical for the professional activity, etc. Some perspectives of cognitive and semiotic approach towards professional discourse study are suggested.
\end{abstract}

Keywords: professional discourse; semiotics; cognitive linguistics; terminology; conceptual metaphor.

\section{Introduction}

The fact that discourse has been the subject of researchers' interest for several decades can be explained by the central position it holds in the language functioning as well as by its complex nature involving all spheres of the person's life. This intertwinement can also be the reason for the multidisciplinary character of discourse study and application of different approaches towards its research in the framework of pragmatics, psycholinguistics, sociolinguistics, functional stylistics, semiotics.

Initially the main aim of the study was to differentiate the discourse from the text, the taxonomic and structural methods were applied to linguistic and anthropological research (van Dijk, 1985), while later scholars began to consider discourse as a set of social practices, constructing and reconstructing concepts and ideas.

Nowadays investigators have started looking into the specific character of various types of discourse and the description of their structural, cognitive and pragmatic characteristics. Moreover, widening of the range of problems in discourse studies goes along with greater differentiation and classification of the language matter which contributes to analyzing new types of discourse. Among them professional discourse is the less studied one in spite of it being socially and heuristically important.

\section{Defining Professional Discourse}

Trying to define professional discourse we start with the general characteristic of discourse according to which it is analyzed in the light of extra linguistic character and social factors. The basis for the definition can be found in the semiotic definition of discourse given by A. J. Greimas and J. Courtes (1979), who state that discourse as the semiotic process appears as a set of discursive practices: linguistic practices (verbal behavior) and non-linguistic practices (signifying somatic behavior manifested by the sensory orders). The context factor - situations and types of interaction typical for professional communication - appears to be specifically important for professional discourse. 
Professional discourse intertwines with scientific, workplace, institutional or some other types of discourse. Scientific discourse of a particular domain constitutes part of general scientific discourse and is included in the core of professional discourse. Workplace discourse comprises texts relating to people's activity in various organizations. Institutional discourse is presented by texts and talks determined by the set of social roles (Karasik, 2000). V.I. Karasik analyzing institutional discourse characterizes typical agents and clients, the chronotopos, the purpose, values, strategies, genres, precedent texts and discursive formulas. Professional discourse is close to institutional one but is not confined to it. The formal professional interaction can be analyzed from the institutional perspective, while informal professional communication needs a different approach.

B.L. Gunnarsson in the book "Professional discourse" (2009) uses the term "professional discourse" to refer to text and talk in professional contexts. Professional here is the synonym of "paid-work related" covering both skilled and unskilled paid jobs. The author distinguishes the following features of professional discourse. Expert character of professional discourse is reflected in terminology, text genres, conversation patterns which vary from domain to domain. Next, professional discourse has explicit goals and occurs in professional situations which specify the participants, place and communicative event. Moreover, professional discourse is strongly conventionalized. The further point mentioned by the author is the fact that professional discourse is part of a "socially organized and structured set of activities within a workplace unit" (Gunnarsson, 2009:8). Another feature of professional discourse is its dependence on different societal framework systems such as legal-societal, technical-economical, socio-cultural and linguistic. Undoubtedly a lot of documents as well as communication rules appear as a result of internal or external regulations. Rapidly developing technology influences professional discourse as well. Socio-cultural and linguistic frameworks are taken into account as life generally and professional life in particular is becoming more and more culturally, socially and linguistically diverse. The last distinguished feature is dynamic character of professional discourse, which is witnessed in the type of knowledge and skills necessary for professional communication at different stages, changes in the labour market and politics, globalization of economy.

Thus, we see that professional discourse can be analyzed from different perspectives, such as philosophical, epistemological, sociological, etc. We assume that professional discourse is a combination of the corpus of texts and talks united by professional world view, thesaurus, the theme, genre together with extralinguistic factors which are determined by the person's professional activity.

\section{Cognitive Approach to Professional Discourse Study}

Professional world view is inseparable part of professional discourse. Shared professional world view determines the success of communication and is based on the knowledge of related science, as well as typical contexts.

Professional world view is the basis for professional consciousness which can be defined as the phenomenon which reflects definite professional activity and whose function is regulation of the person's social activity in some professional sphere.

A.A. Angelovskii (2010) studying the structure of professional consciousness distinguishes three components: epistemological, practical and axiological.

The epistemological component is constituted by theoretical and historical scientific knowledge which is necessary for the type of professional discourse; basic ideas of the professional activity, its importance; functions and principles of the profession. The content of this component is determined by the sphere the profession belongs to - technical or humanities. There can be distinguished different types of knowledge - rational and logical, intuitive, perceptive, tacit and explicit. The analysis of different types of professional knowledge and description of nominating process in various types of knowledge are of great importance while categorizing and perceiving information in a definite professional discourse.

The practical component comprises practical skills, professional norms and regulations reflecting peculiarities of this professional activity. The axiological component is the basis for professional ethics, such as behavior norms and patterns of the person as a member of the professional community.

The list of components can be further developed and we can add an ethnocultural component. For instance, there exist ethnic variants of medical professional world view of a Western or Eastern representative, which differ considerably. In the West, medicine is called "medicine of separate organs" as the fundamental method of the therapy is the treatment of disease symptoms, while in the East, the object of the cure is the person's body in the whole: consideration is given to the physical as well as psychological state.

Professional world view incorporates practical knowledge necessary for carrying out practical activity. E.I. Golovanova (2013) while analyzing professional communication distinguishes two basic formats: theoretical, based on rational thinking, and practical, connected with peculiarities of intuitive and imaginative thinking, which relies on sense 
perception of the environment. In some types of discourses (medical, legislative, economical, astrological) where such communication as "specialist vs. non-specialist" is available, these formats are supplied by naïve (commonplace) one, which is characterized by interaction of professional and commonplace beliefs and views.

The essential part of professional world view which differentiates a professional from an outsider is terminology. From the cognitive perspective the term is viewed as a linguistic unit which emerges as a result of interaction between professional consciousness and professional communication. Each type of professional discourse determines the language used while communicating. Generally, we can say that terminology reflects the knowledge structure and the more ancient professional discourse is, the more complicated concept stands beyond the term.

Terms and terminological systems are analyzed with regard to their role in professional communication as well as professional cognition. E. I. Golovanova states that the term is the verbalized result of professional cognition, a means of orientation in professional discourse and is an inseparable part of professional communication. The term is an orientation for cognition as well as for different types of activities (Golovanova, 2008). Shared knowledge of terminology is the basis for professional communication on both national and international levels.

One of the basic means of conceptualization and categorization in professional communication is analogy and metaphor as analogy's manifestation. The analysis of functioning of metaphorical and metonymical models help to reveal the peculiarities of the specialist's professional world view.

Cognitive linguistics postulates that metaphor is not just a trope, but a cognitive mechanism, allowing conceptualization of new ontological phenomena in analogy with already existing state of things. That is the reason why metaphor is given the central position, not periphery one, in the cognitive language model. The development of the cognitive metaphor theory and description of metaphorical models is one of the most promising research in contemporary cognitive linguistics. One of the latest achievements in cognitive linguistics is the theory of conceptual integration developed by M. Turner and G. Fauconnier (1995), who understand metaphor as mental mapping of conceptual source domain onto target domain; at the same time short-term memory preserves blends which are later, at the moment of speech, incorporating into knowledge structure and serve as a fundamental component of cognitive process. The source domains may be connected by different types of relations, such as, analogy and metaphor projection, metonymy transfer, correspondence between function and meaning, etc.

An advantage of conceptual integration model is the fact that it allows to infer and analyze metaphorical dominant ideas in different spheres including professional discourse, which promotes understanding of the world perception by specialists in different professional spheres. For instance, the conceptual analysis of educational medical texts shows that professional consciousness is characterized by biocentrism, and such metaphors as "Person's body - Battle field", "Person's body -Sentient being" are dominant in the process of the person's body conceptualization.

The leading cognitive mechanism forming astrological discourse is the mechanism of analogy among three level elements: the zodiac sign, the house in the horoscope and the planet, such as Sagittarius - Jupiter $-9^{\text {th }}$ house, indicating the direction (sign), scope of application (house), and the energy type (planet). Personification is another feature typical for astrological discourse. Heavenly bodies represent human characters and some aspects of personality: Mars stands for will, Venus means senses, while Mercury - intellect. As for dominant metaphors, they are "Sky is Clock", "Horoscope is Theatre stage", "Horoscope is Life Map" (Aznacheeva, Mamonova, 2012).

One more fundamental cognitive mechanism in professional discourse is metonymy. A. Burkhardt (2011) studying the football language distinguishes three semantic spheres: "game language", "position language", "table/list language". In "game language" metonymy is the leading cognitive mechanism which helps to represent the whole game situation in one element of it, for instance, "corner kick", "penalty kick", "indirect free kick". If we consider astrological discourse, one of the fundamental discourse mechanisms is metonymical transfer from time to place characteristics.

Basic concepts, metaphorical models and types of metonymical transfers make each professional discourse unique and specific.

\section{Semiotic Approach to Professional Discourse Study}

The outstanding feature of semiotics as the science is witnessed in the gap between its practical application and theoretical apprehension. On the one hand, the semiotics theory was developed in the $20^{\text {th }}$ century and one of its founders F. de Saussure while formulating the principles of language semiotic research wrote that semiotics as a science does not exist yet. These days A. Solomonik (2009) still believes that general semiotics in contrast to special semiotics is still in the process of its development. On the other hand, we witness the expansion of the semiotic method onto more and more objects of study, there appear new methodologies targeted not only at social and cultural phenomena but at animal life and inorganic nature as well. What is more, this tendency extends to some former scientific achievements, 
which in hindsight are acknowledged as semiotic studies. For instance, Mendeleev periodic system is viewed as an ideal semiotic system by A. Solomonik (2009). Such extended understanding of semiotics falls into line with Pierce's opinion (2000). Pierce postulates the pan-sign, stating that any object in the Universe can be studied as a sign. Semiotics is interested in anything that can be viewed as the sign. Consequently, any phenomenon is potentially semiotic and whether to study it as a semiotic system element depends on the recipient's willingness to acknowledge it as the result of conscious perception and further formalization. As a result, the notion of semiosphere, as the formalized knowledge, introduced by Y. Lotman spreads to noosphere by V. Vernadskii and even biosphere by L. Gumilev. Any phenomena characterized by the systematic character and consistency may be seen as semiotic system components.

Not only natural language, but speech communication as well has a systematic character and thus can be the object of semiotic research. In its classical variant, semiotic analysis, which was held from the structuralism perspective, had immanent and static character. The objects to study were mainly fiction texts, more seldom scientific texts. As for discourse, it has rarely come into the researchers' light.

We state that the study of professional discourse should be carried on the level of metalanguage of the corresponding science and the level of professional speech communication. The sign character of professional discourse on the metalanguage level is represented by the language for specific purposes; the main body here is compiled by special terminology. Special terms have been deeply studied in the systematic and epistemological school in terminology, which has a long history and has got impressive results. Terminological systems studied in this school possess all characteristics of a semiotic system and thus are actually semiotic, that is highly formalized.

On the level of speech communication the systematic character is witnessed in the organization of speech genres, functioning of intertextual incorporations and precedent texts, recurrence of discursive patterns, particular types of extra linguistic and linguistic contexts which determine interpretation of terms, as well as communicative situations typical for the professional activity. Thematic relations and the structure of terminological systems present a regular hierarchical system. This system iconically reflects the way reality of a particular professional sphere is organized in the person's consciousness. Thus, the terminological system of a particular professional sphere functions both as a system of signs and as a model reflecting a corresponding cognitive macrostructure, that is it is a kind of an icon.

Speech organization of professional discourse has a field structure and contains corresponding fragments of scientific, pedagogical, mass-media and other discourses. For instance, scientific medical texts, texts of institutional formal and informal communication constitute the core of medical discourse; on the close periphery we find educational mass-media materials; the further periphery is occupied by publicist articles, everyday medical talks, etc. This combination of different discourses and speech genres iconically reflect functioning of corresponding social institutes.

Semiotic approach is not restricted to classifications and systematization but takes into account the subjective nature of cognition and social communication. The foundation for this was laid in Ch. Peirce's semiotics conception according to which the main element in the semiosis is an interpreter, as it is he who is responsible for something to be treated as a sign or non-sign and consequently for the semiosis itself (Peirce, 2000). The importance of differentiation between ontological and semiotic reality is postulated by A. Solomonik (2009). He believes that the mankind has no direct access towards ontological reality and thus semiotic reality arising in the process of ontological reality cognition serves a guideline in the person's practical activity.

\section{Conclusion}

In spite of the differences between semiotics and cognitive linguistics they share some peculiarities. First, they are not pure scientific disciplines, rather scientific approaches which can be applied to different objects, though mainly in social sciences and Humanities. Moreover, both disciplines have interdisciplinary character, moderate phenomenology, interest to metaphor and metonymy. Besides, their common tendency is seen in the interest to dynamic aspect of phenomena functioning, denotation and meaning generation process.

The subjective aspect of semiotic research fully manifests itself in R. Barthes' connotative semiotics, one of whose purposes is semiotic analysis of ideology mechanisms and methods of its propaganda. Connotative semiotics which places high emphasis on revealing explicit and tacit types of meaning has a lot in common with cognitive linguistics which analyzes fundamental mechanisms of the person's cognitive activity as well as substantial categories presupposing all types of his social and cultural activity.

The subjective character of cognition reveals itself on the level of terminology, which is proved by lingvo-cognitive terminological research that unlike traditional studies is not descriptive but explanatory. The object of cognitive terminology is language for specific purposes in relation to processes of linguistic categorization and conceptualization as well as cognitive structures of knowledge. Key terminology functions as scientific cognitive units, whose thematic relations 
and structure construct conceptual world view as part of professional world view.

While analyzing professional discourse in the linguistic framework we believe it is promising to study it in a larger context taking into account non-verbal and extralinguistic factors, for instance, systematic study of presuppositions, implications together with such non-verbal elements as gestures, proxemics, oculesics.

\section{Acknowledgements}

The publication was supported by the Russian Science Foundation for Humanities (RGNF), grant N 15-0400455 "Analogue and cognitive processes in linguocreative activity of the personality'.

\section{References}

Angelovskii, A.A. (2010). Analiz ponyatii professiya, professionalnoye soznaniye, professionalnaya deyatelnost, professionalism [The analysis of the notions: profession, professional consciousness, professional activity, professionalism]. Izvestiya Samarskogo nauchnogo tsentra Rossiiskoi akademii nauk, Issue 12, 5(2), 306-314.

Aznacheeva E., \& Mamonova, Y. (2012). Linguistic personality of an astrologer in professional communication. Scientific Enquiry in the Contemporary world: Theoretical Basics and Innovative Approach. Vol.7, 119-121.

Burkhardt, A. (2011). Der deutsche Fußball und seine Sprache. Nebst Kurzporträt eines Wörterbuchprojekts. . [Online] Available: http:/l www.dirk-kemper.de.

Golovanova, E.I. (2008). Cognitivnoye terminovedeniye [Cognitive terminology]. Chelyabinsk: Encyclopedia.

Golovanova, E.I. (2013). Professionalnii diskurs, subdiscurse, zhanr professionalnoy kommunikatsii: sootnosheniye ponyatii [Professional discourse, subdiscourse, genre of professional communication: correlation of the notions]. Vestnik Chelyabinskogo gosudarstvennogo universiteta. Philologiya. Iskustvovedeniye, Issue 73, 1 (292), 32 - 35.

Greimas, A. J., Courtes, J. (1979). Semiotics and Language: An Analytical Dictionary. Bloomington: Indiana University Press.

Gunnarsson, B. L. (2009). Professional Discourse. Bloomsbury Publishing.

Karasik, V.I. (2000). O tipakh diskursa [The types of discourse]. Yazykovaya lichnost, institutsionalnii i personalnii diskurs (pp. 520).Volgograd.

Peirce, Charles S. (2000). Logicheskiye osnovaniya teorii znakov. Sankt-Peterburg, Izd.: "Alteya". Transl. from: Peirce, Charles Sanders (1931-1958). Logical Foundations of the Theory of Signs. Harvard University Press, 1931-1958, Dover publications, Inc. 1958.

Solomonik, A. (2009). Ocherk obschei semiotiki [An essay on general semiotics]. Minsk: MET.

Turner, M. \& Fauconnier, G., (1995). Conceptual integration and formal expression. Metaphor and Symbolic Activity, Vol. 10, 3, 183-204.

Van Dijk, T.A. (1985). Introduction: Discourse analysis as a new cross-discipline. van Dijk, (Ed.) Handbook of Discourse Analysis. Vol. 1.( pp.1-10). London: Academic Press. 